University for Business and Technology in Kosovo

UBT Knowledge Center

Oct 28th, 9:00 AM - Oct 30th, 5:00 PM

\title{
Climatic Conditions and Other Resources for Kosovo Transition to "SES" and His Vision
}

Vehebi Sofiu

University for Business and Technology, vehebi.sofiu@ubt-uni.net

Follow this and additional works at: https://knowledgecenter.ubt-uni.net/conference

Part of the Engineering Commons, and the Physical Sciences and Mathematics Commons

\section{Recommended Citation}

Sofiu, Vehebi, "Climatic Conditions and Other Resources for Kosovo Transition to "SES" and His Vision" (2016). UBT International Conference. 41.

https://knowledgecenter.ubt-uni.net/conference/2016/all-events/41

This Event is brought to you for free and open access by the Publication and Journals at UBT Knowledge Center. It has been accepted for inclusion in UBT International Conference by an authorized administrator of UBT Knowledge Center. For more information, please contact knowledge.center@ubt-uni.net. 


\title{
CLIMATIC CONDITIONS AND OTHER RESOURCES FOR KOSOVO TRANSITION TO "SES"AND HIS VISION
}

\author{
Vehebi Sofiu \\ UBT - Higher Education Institution, Lagjja Kalabria, 10000 p.n., \\ Prishtine, Kosovo \\ vehebi.sofiu@ubt-uni.net
}

\begin{abstract}
Developing modern technologies have made possible finding of alternative opportunities for exploitation of natural resources in order to meet the energy demands. Renewable energy is a good opportunity of meeting the environmental requirements and functioning of the applicable techniques system with an efficacy and efficiency using. Natural resources owned by Kosovo, with the main resource of coal as the only opportunity for energy generation, which is also the biggest polluter in the country has increased the requirements of continuous research, which of the types of energy (alternative energy) is likely optimal to be put into operation. Measurements, studies and ongoing researches on the efficiency of solar radiation, the effects of pollution of the fossils on the surface of solar panels, as well as the weather conditions as geographical position that has Kosovo, they have increased the presence of sophisticated techniques including the energy transition that the country is facing as a necessity generation. Measurement of solar radiation in some locations of Kosovo for the intensity of current and voltage, when the solar panels have been under contaminated aerosols and when the panels have been cleaned of particulate pollutants, as radiant efficiency in comparison of the data eliminates every dilemma of the exterior factors that requirements for use of renewable energy have occupied a special place in the world of developed technology. Climatic monitoring conditions for each contaminated element hold in themselves an hope for a practical advanced opportunity towards sustainable development that Kosovo has a favorable geographical position and favorable climatic conditions for solar energy and other energy sources to put in use a new energy strategy, including the opportunity to generate $100 \%$ of the clean energy.
\end{abstract}

Keywords: Climatic Condition, Effect of aerosol, Sustainable energy system, Reneveable Energy, Geografical postion.

\section{Introduction}

Management of data on air quality monitoring stations in a central electronic action, Establishment of new generation capacity according to the model RES of the EU Directives, Development of a visionary strategy for the future with $100 \%$ clean energy.

Based on the processes data of Kosovo Hydro metrological Institute and other institutions without dependent on research of natural resources table 1 . 
Book of Proceedings

International Conference on Mechatronics, Sciences in Energy Efficiency Engineering,

System Engineering and Robotics

Table 1: Measuring intensity of current, voltage and solar radiation when panel is clean

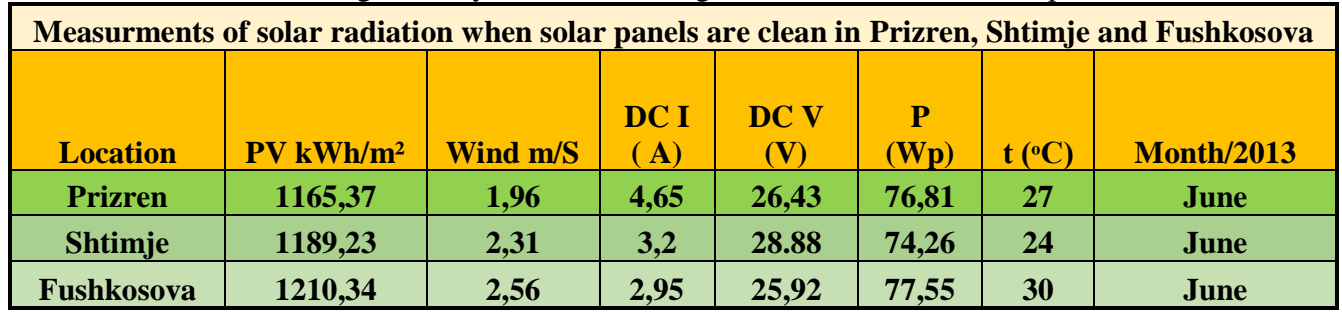

Solar- analysis of solar radiation - Measurements of solar radiation with instrument MP 100 and MP 200 (Solar meter) and comparative analysis data of efficiently pollution aerosol particles[1].

Table 2: Measuring the polluting particles with aerosol effects

\begin{tabular}{|c|c|c|c|}
\hline $\begin{array}{c}\text { Without pollution / } \\
\mathbf{g} / \mathbf{m m}^{\mathbf{3}}\end{array}$ & $\begin{array}{c}\text { With pollution } \\
/ \mathbf{g} / \mathbf{m m}^{\mathbf{3}}\end{array}$ & $\begin{array}{c}\text { Pollution particles / } \\
\mathbf{g} / \mathbf{m m}^{\mathbf{3}}\end{array}$ & \% \\
\hline 2.041435 & 2.323325 & 0.28189 & 12.13304 \\
\hline 2.018494 & 2.209853 & 0.191359 & 8.659354 \\
\hline 2.072691 & 2.127873 & 0.055182 & 2.593294 \\
\hline 2.057633 & 2.256998 & 0.199365 & 8.833193 \\
\hline
\end{tabular}

The quantity of water flows, spaces of water collection and possibilities of hydropower constructions based on Kosovo strategies and other research including the feasibility of international companies. Measurement of polluting aerosol particles was done in Kosovo Hydro-Meteorological Institute in Pristina, through an international standardized electronic devices figure 1, type of device is CUBIS Sartorius MSA $225 \mathrm{~S}$ with 6 decimal point precision[2].

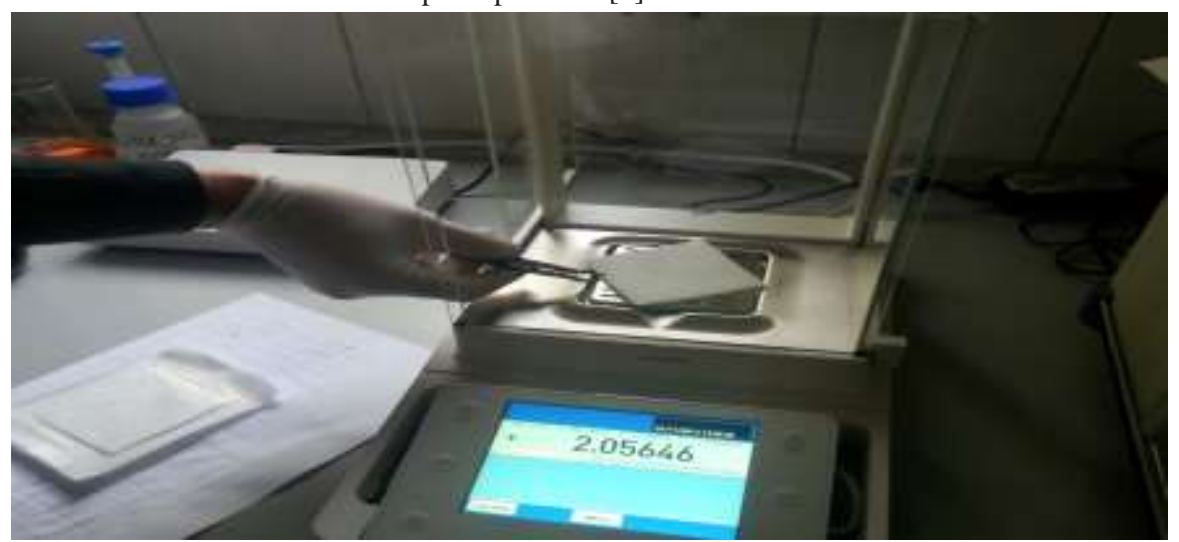

Figure 1: Instrument CUBIS Sartorius MSA $225 \mathrm{~S}$ in six decimals 


\section{CLIMATIC CONDITIONS AND OTHER RESOURCES FOR KOSOVO TRANSITION TO "SES"AND HIS VISION}

Pollution particles collected for a photovoltaic cell module in Shtimje made by an instrument Sartorius Cubis. In continuation, we'll illustrate the measurement of particulate pollutants taken in samples for several periods at the same time and in different seasons[3].

Samples located in a closed bag of sterilized bandageu is measured without contamination expressed in grams (g), then, with the prepared pollution are collected pollutants in a solar panel in those places where panels are placed for public roads lighting in Shtimje, Fushkosove and Prizren. Measurements of particulate pollutants presented in Table 3 are related to different periods according to locations from the time when the solar panels for lighting of public roads are assembled[4,5 ].

Table 3: Presentation of monitoring air quality for Peja, Prizren and Obiliq

\begin{tabular}{|c|c|c|c|c|c|c|}
\hline \multicolumn{7}{|c|}{ MONITORING OF AIR POLLUTION IN PEJA, PRIZREN AND OBILIC FOR } \\
\hline Regions & $\mathrm{SO}_{2}\left(\mathrm{mg} / \mathrm{m}^{3}\right)$ & $\mathrm{NO}_{2}\left(\mathrm{mg} / \mathrm{m}^{3}\right)$ & $\mathrm{O}_{3}\left(\mathrm{mg} / \mathrm{m}^{3}\right)$ & $\mathrm{CO}\left(\mathrm{mg} / \mathrm{m}^{3}\right)$ & $P M 10\left(\mu \mathrm{g} / \mathrm{m}^{3}\right)$ & $P M 2.5\left(\mu \mathrm{g} / \mathrm{m}^{3}\right)$ \\
\hline Peja & 5.63 & 10.93 & 54.43 & 0.66 & 43.1 & 36 \\
\hline Prizren & 6.98 & 21.65 & 97.7 & 0.75 & 50.3 & 35.5 \\
\hline Obilic & 7.86 & 13.92 & 48.3 & 0.629 & 53.1 & 37.3 \\
\hline
\end{tabular}

The conducted measurements related to poluting particles illustrate that Fushkosova is location with higher pollution, as well as Pristina with a large difference in \% figure 2 by solar modules. Automatic monitoring stations with electronic data are located in several cities of Kosovo for measurement of $\mathrm{SO}_{2}, \mathrm{CO}, \mathrm{NO}_{2}, \mathrm{O}_{3}, \mathrm{PM} 10$ and PM 2.5.

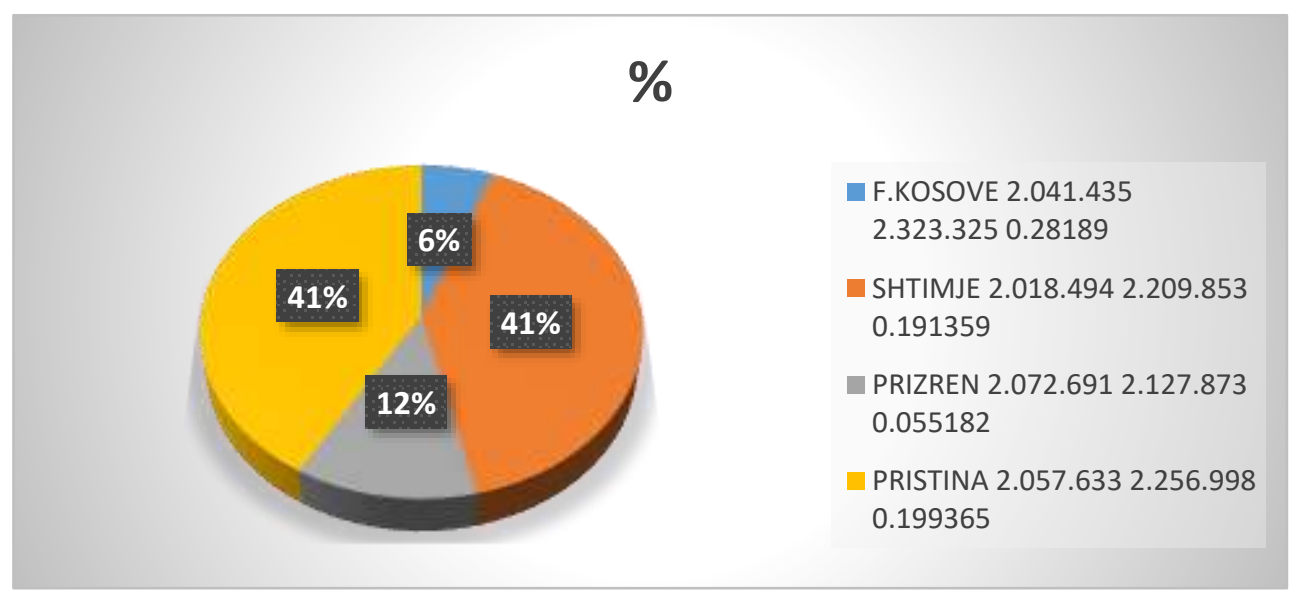

Figure 2: Polluting particles with aerosol effects

These results are derived for the first time, and they have never been processed and managed before. Kosovo lacks a center station regarding to data management, where the relevant institutions will be able to be informed with necessary data of the living environment, where natural resource can be used. The presented extraction of data from electronic monitoring station in Obilic for some types of 
Book of Proceedings International Conference on Mechatronics, Sciences in Energy Efficiency Engineering, System Engineering and Robotics

pollutions including aerosol particles from burning fossil. The TELEDYNE device, reffered as advanced pollution instrument, respectively ANALYZER - MODEL T 300 for monitoring of particulates PM 10 and PM 2.5 in Obilic, at the time of extraction of findings with electronic data [5,6 ].

The data of Kosovo Forestry Agency and possibility of exploitation of this natural resource

The data of thermal energy including studies case for the construction of high buildings and the case of research for the amount of Geothermal for residential buildings, also for areas where the water is heated deep and underground deep[7].

\section{The vision of SES for Kosovo}

The description of factual situation of Kosovo energy system based on: Energy Corporation of Kosovo - KEK Generation of electricity from cool Kosovo transmit ion system - KOSTT transmit ion of electricity- 400/220/110/35 kV / kV / kV / kV Distribution and Supply of electricity- 35/10/04 kV / kV / kV.

The system for the future will be close the generation of burning fossil fuels (coal) to power plants Kosovo A and B, the vision of the future will be $100 \%$ renewable energy, with reducing emissions by looking at the zero value[8].

\section{Vision of SES for Kosovo}

Production of electricity from thermo power plant is $97 \%$ from both generation Kosovo A and B with burning fossils, the technology are old and with massive pollution above the allowed EU norm by Directive 2001/80/EC

Vision for the future - We need a transition to a new, sustainable energy system (SES), which will be durable and without GHG emissions. New system has to fulfill the following 6 criteria:

1. Energy source has to be unlimited and available everywhere on the planet Earth.

2. Energy carrier transformation should be without emissions of GHG.

3. Energy has to be available at all times in all needed energy forms (solid, liquid, gaseous, electricity)

4. New energy system should use existing infrastructure with minor adaptations;

5. In transition period both systems should work in parallel without disturbances.

6. Sustainable energy system has to be competitive with inclusion of all external costs in the price of fossil fuels [10].

\section{Simulation of the Vision for-SES}

Final energy is needed in industry, traffic and domestic, commercial and public use, with common designation ,others".

We can cover those needs:

1037MW from RE in Kosovo can be covert on the end of year 2050 with nvestment in the following infrastructure: 
CLIMATIC CONDITIONS AND OTHER RESOURCES FOR KOSOVO TRANSITION TO "SES"AND HIS VISION

- HE Zhuri 300 MW and small 27 Hydro power around 87 MW

- wind PP $300 \mathrm{MW}$

-200 MW of geothermal PP

- PV PP capacity of $150 \mathrm{MW}$ (area for this $\sim 55 \mathrm{~km} 2$ ) under present building stock in Kosovo is more than $271 \mathrm{~km} 2$. We need to cover only $\sim 25 \%$ of this area).

Using bio waste from forest and fields,

- Investment in geothermal heat, ect [11].

\section{Environmental of consecuensicis of each scenario-}

New Sustainable Energy Concept (SEC) and emissions of CO2, NOx, Co, SO2, Dust to be reduced in minimum. This mean that we have to replace $1137 \mathrm{MW}$ in TPP with the new RE PP. With regard the nominal working hours this mean to build approximately 1.000 - $2000 \mathrm{MW}$ installed power in solar, geothermal or hydro PP, including energy storage capacities.

\section{Conclusions and further research needed}

Available time to change is in the upcoming decades.

Proposed SES for Kosovo enable us to convert present fossil fuels based system to $100 \%$ RE up to 2050.

- Presented energy system is $100 \%$ sustainable.

Those energy carrier, including renewable electricity can use all present energy infrastructure in Kosovo (power and gas lines and pumping station).

Negative impact of this development is expressed in climate change [10-11].

\section{Expected contribution for the science}

The contributions are multidimensional, reduction of air pollution are in zero, for savings of Budget, No more energy import.

SES $100 \%$ RES energy.

To empowered the future generations to conduct the study for future

\section{References:}

1. Soteris A. Kalogirou; Solar Energy Engineering process and systems, second edition, 2014, USA.

2. Renewable energy Sources Energy Efficiency (EERES) -Kosovo [Internet]. Available from: <http://eereskosovo.org/shq/index.php/ee-ne-kosove>Accessed 26 April 2014 


\section{Book of Proceedings}

International Conference on Mechatronics, Sciences in Energy Efficiency Engineering,

System Engineering and Robotics

3. David de Jager, Corinna Klessmann, Eva Stricker, Thomas Winkel, Erika de Visser, Michèle Koper; Final Report, Financing Renewable Energy in the European Energy Market; 2 January 2011.

4. Nathan David, Abioye Ayodeji Opeyemi; Solar Power System: A Viable Renewable Energy Source for Nigeria, September, 2013

5. Renewable Energy in Europe; Markets trends and technologies, second edition, 2010.

6. Electricity from Renewable Resources, Americans Energy Future, the National Academic Press, Washington, 2010.

7. Scientific Assessment of the Effects of Global Change on the United States, A Report of the Committee on Environment and Natural Resources National Science and Technology Council, May 2008

8. Jos g.J. Oliver (PBL) \& Marilena Muntan (IES-JRC) \& Jeroen A.H.W.Peters (PBL), Raport: Trends in Global $\mathrm{CO}_{2}$ Emissions, PBL Netherlands Environmental Assessment Agency The Hague, 2013

9. Scientific Assessment of the Effects of Global Change on the United States, A Report of the Committee on Environment and Natural Resources National Science and Technology Council, May 2008

10. Sustainable energy system with zero emissions of GHG for Cities and Country, Energy and Buildings, ELSEVIER, Peter Novak, 2014

11. Slovenian Energy Concept (SEC) in the light of 5th Report of IPCC, Prof.dr. Peter Novak, Ljubljana. 2015 